\title{
Tsukamurella spongiae sp. nov., a novel actinomycete isolated from a deep-water marine sponge
}

Correspondence

Julie B. Olson

jolson@bama.ua.edu

\author{
Julie B. Olson, ${ }^{1}$ Dedra K. Harmody, ${ }^{2}$ Asim K. Bej ${ }^{3}$ and Peter J. McCarthy ${ }^{2}$ \\ 'Department of Biological Sciences, University of Alabama, Tuscaloosa, AL 35487, USA \\ ${ }^{2}$ Harbor Branch Oceanographic Institution, Division of Biomedical Marine Research, \\ 5600 US 1 North, Fort Pierce, FL 34946, USA
}

${ }^{3}$ Department of Biology, University of Alabama at Birmingham, Birmingham, AL 35294, USA

\begin{abstract}
A Gram-positive, rod-shaped, non-spore-forming bacterium (strain $\mathrm{K} 362^{\top}$ ) was isolated from a deep-water marine sponge collected off the coast of Curaçao in the Netherlands Antilles. On the basis of $16 \mathrm{~S}$ rRNA gene sequence similarities, strain $\mathrm{K} 362^{\top}$ was shown to belong to the genus Tsukamurella, being most closely related to Tsukamurella pulmonis (99.2\%), Tsukamurella tyrosinosolvens (98.9\%), Tsukamurella strandjordii (98.8\%), Tsukamurella pseudospumae $(98.8 \%)$ and Tsukamurella spumae (98.8\%). A combination of the substrate utilization patterns, the fatty acid and mycolic acid profiles and the DNA-DNA hybridization results supported the affiliation of strain $\mathrm{K} 362^{\top}$ to the genus Tsukamurella and enabled the genotypic and phenotypic differentiation of strain $\mathrm{K} 362^{\top}$ from the seven recognized Tsukamurella species. Strain $\mathrm{K} 362^{\top}$ therefore represents a novel species of the genus Tsukamurella, for which the name Tsukamurella spongiae sp. nov. is proposed. The type strain is $\mathrm{K}_{36} 2^{\top}\left(=\mathrm{DSM} 44990^{\top}=\mathrm{NRRL} \mathrm{B}-24467^{\top}\right)$.
\end{abstract}

The genus Tsukamurella was proposed by Collins et al. (1988), the type species being Tsukamurella paurometabola. This taxon currently contains seven species (in addition to the type species) with validly published names. Species recovered from clinical specimens include Tsukamurella inchonensis (Yassin et al., 1995), Tsukamurella pulmonis (Yassin et al., 1996), Tsukamurella strandjordii (Kattar et al., 2001) and Tsukamurella tyrosinosolvens (Yassin et al., 1997). The remaining species were associated with activated sludge foaming and include Tsukamurella pseudospumae (Nam et al., 2004) and Tsukamurella spumae (Nam et al., 2003). These species form a distinct clade within the evolutionary radiation of the mycolate actinomycetes and share very high $16 \mathrm{~S}$ rRNA gene sequence similarity values (Kattar et al., 2001; Nam et al., 2003).

Strain $\mathrm{K} 362^{\mathrm{T}}$ was isolated from a deep-water marine hexactinellid sponge with associated zoanthids collected off the coast of Curaçao (the Netherlands Antilles), at a depth of $220 \mathrm{~m}$, using the Harbor Branch Oceanographic Institution's Johnson-Sea-Link II submersible. A small section of the sponge (approx. $15 \mathrm{~g}$ wet weight, including

The GenBank/EMBL/DDBJ accession number for the 16S rRNA gene sequence of strain $\mathrm{K} 362^{\top}$ is $\mathrm{AY} 714239$.

The fatty acid profiles of strain $\mathrm{K} 362^{\top}$ and other species of the genus Tsukamurella are presented in a supplementary table with the online version of this paper. both the pinacoderm and mesohyl regions) was gently rinsed in sterile natural seawater, cut into smaller pieces and then homogenized at low speed (5000 r.p.m.) with an ethanol-sterilized high-speed homogenizer (VirTis). The sponge suspension was heat-treated $\left(70{ }^{\circ} \mathrm{C}\right.$ for $\left.15 \mathrm{~min}\right)$ and plated onto maltose-seawater agar (Olson et al., 2000). Strain $\mathrm{K} 362^{\mathrm{T}}$ was isolated after 28 days incubation in the dark at ambient temperature $\left(20-25^{\circ} \mathrm{C}\right)$. Colonies were transferred to fresh plates of the isolation media and ultimately maintained on slants of marine agar 2216 (Becton Dickinson). Morphological observations were made with a light microscope (BH-2; Olympus), using cultures grown in marine broth [5 g peptone, $1 \mathrm{~g}$ yeast extract, $1 \mathrm{ml}$ trace metal solution (Olson et al., 2000), 11 artificial seawater (Sieburth, 1979)].

Tolerance of various temperatures $(10,25,30,37,46$ and $\left.55{ }^{\circ} \mathrm{C}\right)$ was tested using marine agar. Tolerance of salt $(\mathrm{NaCl}$ at $0,0.5,1.0,2.0,3.0$ and $4.0 \%, \mathrm{w} / \mathrm{v} ; \mathrm{KCl}$ at $0,1.0,2.0,3.0$ and $4.0 \%, \mathrm{w} / \mathrm{v})$ was determined using modified marine broth (5 $\mathrm{g}$ peptone, $1 \mathrm{~g}$ yeast extract, $1 \mathrm{ml}$ trace metal solution, $1 \mathrm{l}$ distilled $\mathrm{H}_{2} \mathrm{O}$ ) at $22^{\circ} \mathrm{C}$ with agitation.

The ability of the organism to grow on a range of sole carbon sources was examined using the basal medium of Boiron et al. (1993) and the methods employed by Nam et al. (2003, 2004). Fatty acid and mycolic acid analyses were performed on a fee-for-service basis by Microbial ID, Inc. (USA), using 
strain $\mathrm{K} 362^{\mathrm{T}}$ grown on nutrient agar at room temperature for $48-72 \mathrm{~h}$.

Extraction of genomic DNA and PCR amplification using universal bacterial primers $8 \mathrm{~F}$ and $1492 \mathrm{R}$ were performed as described by Olson et al. (2002). Amplified fragments were ligated into plasmid pCR 2.1 (TA cloning kit; Invitrogen) and used to transform Escherichia coli according to the manufacturer's instructions. Plasmids with inserts of the correct size were sequenced at the Macrogen (Korea) sequencing facility.

Total genomic DNA from strains $\mathrm{K} 362^{\mathrm{T}}, T$. pulmonis IMMIB D- $1321^{\mathrm{T}}$ and T. strandjordii BAA- $173^{\mathrm{T}}$ was purified using the procedure described by Ausubel et al. (1987). Genomic DNA $(500 \mu \mathrm{g})$ from each strain was sonicated to generate DNA fragments of 400-600 bp. The concentration and purity of the resulting DNA were determined from the $A_{260}$ and the $A_{260} / A_{280}$ ratio.

Melting temperatures $\left(T_{\mathrm{m}}\right)$ were determined using previously described procedures (De Ley et al., 1970; Gillis et al., 1970). DNA $(30 \mu \mathrm{g})$ from each of the three strains was denatured in $16 \times$ SSC buffer ( $\mathrm{pH}$ 7.0) by increasing the temperature of the sample from 32 to $98^{\circ} \mathrm{C}$ (at a rate of $0.7-1.0^{\circ} \mathrm{C} \mathrm{min}^{-1}$ ); optical density measurements were then recorded at $260 \mathrm{~nm}$. The melting-temperature analysis was confirmed in $16 \times$ SSC buffer ( $\mathrm{pH}$ 7.0) by using SYBR Green I (Roche Applied Science) double-stranded DNAbinding dye and a Cepheid Smart Cycler instrument
(Panicker et al., 2004). The $T_{\mathrm{m}}$ values for each DNA sample were recorded from the fluorescent readings obtained with the SYBR Green I dye following $50 \%$ dissociation of the DNA. The DNA G $+\mathrm{C}$ content was determined by using the equation of Xu et al. (2000) with the value for $\mathrm{G}+\mathrm{C}$ content $(\mathrm{mol} \%)$ for $T$. pulmonis as reported by Yassin et al. (1996).

DNA-DNA hybridization was performed by using DNA reassociation kinetics as described previously (De Ley et al., 1970; Johnson, 1985). Purified, sonicated genomic DNA $(65 \mu \mathrm{g})$ from each strain was used according to the protocol of Pikuta et al. (2005).

On marine agar, strain $\mathrm{K} 362^{\mathrm{T}}$ formed dry, matte, creamcoloured colonies with irregular spreading margins and raised, wrinkled, rough centres. Wet mounts prepared from cells grown in marine broth showed large clusters of nonmotile short rods $(1 \times 2-5 \mu \mathrm{m})$. Strain $\mathrm{K} 362^{\mathrm{T}}$ showed growth at $0-4 \% \mathrm{KCl}$ and $\mathrm{NaCl}(\mathrm{w} / \mathrm{v})$, the optimum salt concentration being $0-1 \%(\mathrm{w} / \mathrm{v})$.

A comparison of substrate utilization patterns showed strain $\mathrm{K} 362^{\mathrm{T}}$ to be distinct from the recognized species of the genus Tsukamurella. Some characteristic and differential properties of Tsukamurella species are given in Table 1. The fatty acid composition of strain $\mathrm{K} 362^{\mathrm{T}}$ was found to be typical of those of members of the genus Tsukamurella (see the comparison with other species presented in Supplementary Table S1, available in IJSEM Online) and was composed of

Table 1. Phenotypic properties that distinguish strain $\mathrm{K} 362^{\top}$ from the type strains of species of the genus Tsukamurella

Strains: 1, strain $\mathrm{K} 362^{\mathrm{T}} ; 2$, T. pseudospumae $\mathrm{N} 1176^{\mathrm{T}} ; 3$, T. inchonensis IMMIB D-771 ${ }^{\mathrm{T}} ; 4$, T. paurometabola DSM $20162^{\mathrm{T}}$; 5, T. pulmonis IMMIB D-1321 $1^{\mathrm{T}}$; 6, T. spumae N1171 ${ }^{\mathrm{T}}$; 7, T. strandjordii ATCC BAA-173 ${ }^{\mathrm{T}}$; 8, T. tyrosinosolvens IMMIB D-1397 ${ }^{\mathrm{T}}$. Data for recognized species are taken from Nam et al. $(2003,2004)$. +, Positive; -, negative.

\begin{tabular}{|c|c|c|c|c|c|c|c|c|}
\hline Characteristic & 1 & 2 & 3 & 4 & 5 & 6 & 7 & 8 \\
\hline \multicolumn{9}{|c|}{ Growth on sole carbon sources: } \\
\hline$(+)$-D-Arabinose & - & + & + & - & + & - & - & + \\
\hline$(+)$-L-Arabinose & + & + & - & - & + & + & - & + \\
\hline$(+)$-D-Cellobiose & + & - & - & - & + & - & - & + \\
\hline Dulcitol & - & - & - & - & + & + & - & + \\
\hline meso-Erythritol & - & - & - & - & + & + & - & + \\
\hline$(+)$-D-Fructose & + & + & - & + & + & + & - & + \\
\hline$(+)$-D-Maltose & - & + & + & - & + & + & - & + \\
\hline$(+)$-D-Salicin & + & - & + & + & + & - & + & + \\
\hline$(-)$-D-Sorbitol & + & - & + & - & - & + & + & + \\
\hline$(+)$-D-Xylose & + & - & + & + & + & + & - & + \\
\hline
\end{tabular}


$\mathrm{C}_{18: 1} \omega 9 c(40.7 \%), \mathrm{C}_{16: 0}(27.7 \%)$, summed feature 3 $\left(\mathrm{C}_{16: 1} \omega 7 c\right.$ and/or $\mathrm{C}_{15}$ iso $\left.2-\mathrm{OH} ; 10.3 \%\right), \mathrm{C}_{20: 1} \omega 9 c$ $(8.5 \%), \mathrm{C}_{14: 0}(3.8 \%), \mathrm{C}_{18: 0}(3.0 \%)$, tuberculostearic acid $(1.5 \%), \mathrm{C}_{20: 0}(1.1 \%), \mathrm{C}_{17: 0}(0.86 \%)$, summed feature $6 / 7$ $\left(\mathrm{C}_{19: 1} \omega 9 c\right.$ and/or $\left.\mathrm{C}_{19: 1} \omega 11 c ; 0.70 \%\right), \mathrm{C}_{17: 1} \omega 8 c(0.66 \%)$, $\mathrm{C}_{15: 0}(0.56 \%), \mathrm{C}_{16: 1} \omega 9 c(0.54 \%)$ and $\mathrm{C}_{12: 0}(0.25 \%)$. Analysis of the mycolic acids indicated that those present in strain $\mathrm{K}_{362}{ }^{\mathrm{T}}$ (number of carbon atoms: 58-75) were also typical of those present in other tsukamurellae and that the size range of the mycolic acids was representative of that of recognized Tsukamurella strains (64-78 carbon atoms; Collins et al., 1988).

The 16S rRNA gene sequence of strain $\mathrm{K} 362^{\mathrm{T}}$ was a continuous stretch of $1480 \mathrm{bp}$. The levels of sequence similarity with respect to other tsukamurellae in GenBank were as follows: $99.2 \%$ (over 1464 bases) for T. pulmonis, 98.9\% (over 1480 bases) for T. tyrosinosolvens and $98.8 \%$ for $T$. strandjordii, T. pseudospumae and T. spumae.

The $T_{\mathrm{m}}$ of the genomic DNA of strain $\mathrm{K} 362^{\mathrm{T}}$ was $75 \pm$ $0.85^{\circ} \mathrm{C}$ (mean \pm SD, $n=3$ ), whereas it was $73 \pm 0.3^{\circ} \mathrm{C}$ for $T$. pulmonis IMMIB D- $1321^{\mathrm{T}}$ and $62 \pm 1.6^{\circ} \mathrm{C}$ for T. strandjordii BAA- $173^{\mathrm{T}}$. No significant differences in the $T_{\mathrm{m}}$ values determined with the spectrophotometer and the Cepheid Smart Cycler were noticed. The G $+\mathrm{C}$ content of the DNA of strain $\mathrm{K} 362^{\mathrm{T}}$ is $74.6 \mathrm{~mol} \%$.

DNA-DNA hybridization between strain $\mathrm{K} 362^{\mathrm{T}}$ and closely related strains (selected on the basis of $16 \mathrm{~S}$ rRNA gene sequence similarity) was performed. The levels of relatedness between strain $\mathrm{K} 362^{\mathrm{T}}$ and T. pulmonis IMMIB D-1321 ${ }^{\mathrm{T}}$ $\left[48 \pm 1.3 \%(\right.$ mean $\pm \mathrm{SD}, n=3)$ ], strain $\mathrm{K} 362^{\mathrm{T}}$ and T. strandjordii BAA-173 ${ }^{\mathrm{T}}(44 \pm 1.2 \%)$, and T. pulmonis IMMIB D- $1321^{\mathrm{T}}$ and T. strandjordii BAA- $173^{\mathrm{T}}(41 \pm 0.8 \%)$ indicate that strain $\mathrm{K} 362^{\mathrm{T}}$ can be considered as a novel taxon.

On the basis of phenotypic and genotypic characteristics (cellular and colonial morphology, salt tolerance, the substrate utilization pattern, the fatty acid and mycolic acid profiles, 16S rRNA gene sequence and DNA-DNA hybridization data), strain $\mathrm{K} 362^{\mathrm{T}}$ represents a novel species of the genus Tsukamurella, for which the name Tsukamurella spongiae sp. nov. is proposed.

\section{Description of Tsukamurella spongiae sp. nov.}

Tsukamurella spongiae (spon'gi.ae. L. gen. n. spongiae of a sponge, referring to the source of isolation, a deep-water sponge).

Aerobic, Gram-positive, non-motile, non-spore-forming actinomycete. Cells are straight to slightly curved rods. Growth is observed on brain-heart infusion agar, nutrient agar and marine agar after $24-48 \mathrm{~h}$ incubation at ambient temperature (approx. $25^{\circ} \mathrm{C}$ ). Optimal temperature for growth is $25-37^{\circ} \mathrm{C}$. No growth occurs at $10^{\circ} \mathrm{C}$ or above $45^{\circ} \mathrm{C}$. On all media, colonies are dry, matte and creamcoloured with irregular spreading margins and raised, wrinkled, rough centres. Colonies range in size from 2 to
$5 \mathrm{~mm}$ in diameter and show irregular elevation. Utilizes $(+)$-D-galactose, $(+)$-D-glucose, $(+)$-D-mannose, $\alpha$-Lrhamnose, (+)-D-sucrose and $(+)$-D-trehalose as sole carbon sources, in addition to those listed in Table 1. Does not utilize amyl alcohol $(1 \%, \mathrm{v} / \mathrm{v})$ or methanol $(1 \%, \mathrm{v} / \mathrm{v})$. Tolerates $\mathrm{NaCl}$ concentrations up to $4 \%$, but growth is enhanced at lower salt concentrations. The major cellular fatty acids of the type strain are $\mathrm{C}_{18: 1} \omega 9 c(40.7 \%), \mathrm{C}_{16: 0}$ $(27.7 \%)$ and $\mathrm{C}_{16: 1} \omega 7 c$ and/or $\mathrm{C}_{15}$ iso $2-\mathrm{OH}(10.3 \%)$. Tuberculostearic acid (1.5\%) is also present. Contains mycolic acids with 58-75 carbon atoms.

The type strain, strain $\mathrm{K} 362^{\mathrm{T}}\left(=\mathrm{DSM} 44990^{\mathrm{T}}=\mathrm{NRRL}\right.$ B-24467 $7^{\mathrm{T}}$ ), was isolated from a deep-water sponge collected off the coast of Curaçao in the Netherlands Antilles, at a depth of $220 \mathrm{~m}$.

\section{Acknowledgements}

We wish to thank Drs J. Euzéby and H. Trüper for assistance with nomenclature, Dr T. Neblett for isolation work, Dr R. Findlay for editorial suggestions, and the crews of the R/V Edwin Link and the JSL II submersible for sample collection. This paper is Harbor Branch Oceanographic Institution contribution number 1654.

\section{References}

Ausubel, F. M., Brent, R., Kingston, R. E., Moore, D. D., Sideman, J. G., Smith, J. A. \& Struhl, K. (1987). Current Protocols in Molecular Biology. New York: Wiley.

Boiron, P., Provost, F. \& Duport, B. (1993). Laboratory Methods for the Diagnosis of Nocardiosis, pp. 107-126. Paris: Institut Pasteur.

Collins, M. D., Smida, J., Dorsch, M. \& Stackebrandt, E. (1988). Tsukamurella gen. nov., harboring Corynebacterium paurometabolum and Rhodococcus aurantiacus. Int J Syst Bacteriol 38, 385-391.

De Ley, J., Cattoir, H. \& Reynaerts, A. (1970). The quantitative measurements of DNA hybridization from renaturation rates. Eur $J$ Biochem 12, 133-142.

Gillis, M., De Ley, J. \& De Cleene, M. (1970). The determination of molecular weight of bacterial genome DNA from renaturation rates. Eur J Biochem 12, 143-153.

Johnson, J. L. (1985). DNA reassociation and RNA hybridization of bacterial nucleic acids. Methods Microbiol 18, 33-74.

Kattar, M. M., Cookson, B. T., Carlson, L. D., Stiglich, S. K., Schwartz, M. A., Nguyen, T. T., Daza, R., Wallis, C. K., Yarfitz, S. L. \& Coyle, M. B. (2001). Tsukamurella strandjordae sp. nov., a proposed new species causing sepsis. J Clin Microbiol 39, 1467-1476.

Nam, S.-W., Chun, J., Kim, S., Kim, W., Zakrzewska-Czerwinska, J. \& Goodfellow, M. (2003). Tsukamurella spumae sp. nov., a novel actinomycete associated with foaming in activated sludge plants. Syst Appl Microbiol 26, 367-375.

Nam, S.-W., Kim, W., Chun, J. \& Goodfellow, M. (2004). Tsukamurella pseudospumae sp. nov., a novel actinomycete isolated from activated sludge foam. Int J Syst Evol Microbiol 54, 1209-1212.

Olson, J. B., Lord, C. C. \& McCarthy, P. J. (2000). Improved recoverability of microbial colonies from marine sponge samples. Microb Ecol 40, 139-147.

Olson, J. B., Harmody, D. K. \& McCarthy, P. J. (2002). Alphaproteobacteria cultivated from marine sponges display branching rod morphology. FEMS Microbiol Lett 211, 169-173. 
Panicker, G., Vickery, M. C. \& Bej, A. K. (2004). Multiplex PCR detection of clinical and environmental strains of Vibrio vulnificus in shellfish. Can J Microbiol 50, 911-922.

Pikuta, E. V., Marsic, D., Bej, A., Tang, J., Krader, P. \& Hoover, R. B. (2005). Carnobacterium pleistocenium sp. nov., a novel psychrotolerant, facultative anaerobe isolated from permafrost of the Fox Tunnel in Alaska. Int J Syst Evol Microbiol 55, 473-478.

Sieburth, J. M. (1979). In Sea Microbes, p. 125. Oxford University Press: New York.

Xu, H.-X., Kawamura, Y., Li, N., Zhao, L., Li, T.-M., Li, Z.-Y., Shu, S. \& Ezaki, T. (2000). A rapid method for determining the $\mathrm{G}+\mathrm{C}$ content of bacterial chromosomes by monitoring fluorescence intensity during DNA denaturation in a capillary tube. Int $J$ Syst Evol Microbiol 50, 1463-1469.

Yassin, A. F., Rainey, F. A., Brzezinka, H., Burghardt, J., Lee, H. J. \& Schaal, K. P. (1995). Tsukamurella inchonensis sp. nov. Int J Syst Bacteriol 45, 522-527.

Yassin, A. F., Rainey, F. A., Brzezinka, H., Burghardt, J., Rifai, M., Seifert, P., Feldmann, K. \& Schaal, K. P. (1996). Tsukamurella pulmonis sp. nov. Int J Syst Bacteriol 46, 429-436.

Yassin, A. F., Rainey, F. A., Burghardt, J., Brzezinka, H., Schmitt, S., Seifert, P., Zimmermann, O., Mauch, H., Gierth, D. \& other authors (1997). Tsukamurella tyrosinosolvens sp. nov. Int J Syst Bacteriol 47, 607-614. 